\title{
Competitive Capacity of Native Species From the Carajás National Forest, Brazil
}

\author{
Rafael G. Viana ${ }^{2}$, Kaléo D. Pereira ${ }^{1}$, Alexandre F. Castilho ${ }^{3}$, Yanna K. S. Costa ${ }^{1}$, Cintia H. Marega ${ }^{4}$, \\ Mailson F. Oliveira ${ }^{5,6}$, Roberthi A. C. Teixeira ${ }^{4}$, Amanda K. I. Ferreira ${ }^{4}$, Raildo K. A. Braga ${ }^{4}$, \\ Renata T. S. Santos ${ }^{5,6}$, Tayla S. Sousa ${ }^{4} \&$ Tulio W. F. Nunes ${ }^{4}$ \\ ${ }^{1}$ Federal University of Viçosa, Viçosa, Brazil \\ ${ }^{2}$ Institute of Agricultural Science, Federal Rural University of Amazon, Belém, Brazil \\ ${ }^{3}$ Environmental Management, Vale S.A., Parauapebas, Brazil \\ ${ }^{4}$ Federal Rural University of Amazon, Parauapebas, Brazil \\ ${ }^{5}$ Department of Biology Applied to Agriculture, São Paulo State University, Jaboticabal, Brazil \\ ${ }^{6}$ Department of Rural Engineering, São Paulo State University, Jaboticabal, Brazil \\ Correspondence: Kaléo D. Pereira, Department of Statistics, Federal University of Viçosa, Viçosa, Brazil. Tel: \\ 55-0319-7311-1381. E-mail: kaleoef@gmail.com
}

Received: August 3, 2018

doi:10.5539/jas.v10n11p471
Accepted: September 2, $2018 \quad$ Online Published: October 15, 2018

URL: https://doi.org/10.5539/jas.v10n11p471

\begin{abstract}
The present research had the objective to use the factor analysis in the evaluation of the competitive capacity of three native species from the Carajás National Forest in competition with different plant densities of the Urochloa brizantha grass. The experiment was conducted in a greenhouse and consisted in planting pots with the native species Bauhinia longipedicellata, Mimosa acutistipula and Solanum crinitum in competition with the exotic grass Urochloa brizantha. The exotic grass was established at densities ranging from 1 to 5 plants per pot, composing a $3 \times 5$ factorial arrangement with four replications that were delineated completely at random. Data were submitted to factor analysis for further analysis of variance and Tukey's test at a 0.05 level of significance with the extracted factors. The effects of $U$. brizantha densities were evaluated by regression analysis. Out of the four extracted factors, three could be interpreted and were defined as vegetative growth index, infestation density index and physiological quality index. The Solanum crinitum species was slightly greater than the others in terms of vegetative growth rate and physiological quality. Generally speaking, native species maintain their vegetative growth in competitive conditions with up to two Urochloa brizantha plants; above that, the vegetative growth index tends to zero, while the infestation density index becomes positive.
\end{abstract}

Keywords: factor analysis, recovery of degraded areas, Urochloa brizantha, weeds

\section{Introduction}

The creation of the National Forest of Carajás had the searches for mineral deposits as a determining factor. In the 60's, geologists from several institutions in the state of Pará carried out the geological reconnaissance program in the Fresco river basin, in order to evaluate occurrences of carbonaceous material (Pereira, Santos, \& Carvalho, 1993). In terms of vegetation, the National Forest of Carajás is home to two very distinct phytogeographic environments: one typically arboreal, represented by the Ombrophilous Forest in its different facies; and an herbaceous-shrub formation, called Savana Metalófila (IBGE, 2012).

In a study conducted by Golder Associates (2008), the occurrence of 23 endemic plant species was investigated: 19 were considered potentially new to science and 22 are threatened species in the National Forest of Carajás. The occurrence of exotic species has been reported frequently, with predominating species from the genus Urochloa. Currently, invasive alien species are recognized as the world's second cause of biological diversity loss, with impacts that are equivalent to those generated by climate changes, since the invasion of plant species have increased in frequency and extension with the growing globalization and anthropic disturbances (Levine \& D’Antonio, 1999). 
The introduction of grasses from the genus Urochloa in the National Forest of Carajás was promoted mainly for its use in erosion control and slope stabilization programs, due to the ease of seed acquisition, tolerance to low soil fertility and rapid soil cover (Cavalcanti Filho et al., 2008; Holanda, Rocha, \& Oliveira, 2008). Due to the worrying natural expansion of areas with exotic grasses and the loss of biodiversity, projects for the suppression of invasive alien species and restoration of native vegetation have been initiated.

The degree of the effects resulting from the interference between cultivated plants and weeds depends on factors related to the weed community (floristic composition, density and distribution), to the crop itself (genus, species or cultivar, spacing between furrows and sowing density) and to the environment (Pitelli, 1985; Kuva et al., 2001; Carvalho et al., 2011). It is important to emphasize that intra or interspecies interference is a reciprocal process, that is, the cultivated or native species also has the capacity to limit the development of weeds (Kuva et al., 2000).

Studies on the competitiveness of native species can help designing more efficient weed management plans, since they provide information on the effects involved in the competition (Bianchi, Fleck, \& Lamego, 2006; Rigoli et al., 2008). The competitive ability is characterized by the dominance of an individual over those surrounding it, which simultaneously use the same resources with limited availability (Aarssen, 1983). According to Goldberg and Landa (1991) the competitive capacity of a species can be assessed by its resistance to interferences generated by neighboring plants, or by inhibiting the growth of a neighboring individual due to the establishment of the species of interest.

In the case of researches using the ideas of Goldberg and Landa (1991) simultaneously, in terms of morphology and physiology, the resulting gross product is certainly an extensive set of data, whose analysis becomes expensive and difficult to interpret in practice. When it comes to a database with many correlated variables, it is interesting to use multivariate analyses that make it possible to reduce data dimensionality, such as factorial analysis or factor analysis. Costa, Souza and Gouvea (2007) define the analysis of factors as a multivariate technique that, depending on the variables (correlation or covariance), makes it possible to generate a smaller set of variables, called latent factors or variables.

Considering the recomposition of the native flora of National Forest of Carajás, the objective of this research was to apply the factor analysis on the evaluation of the competitive capacity of three native species in competition with different plant densities of the Urochloa brizantha grass.

\section{Material and Methods}

The experiment was carried out in a greenhouse located in an experimental area in the Carajás National Forest region, Eastern Amazon, Brazil. The climate of the region is tropical hot and humid, classified as 'Aw' according to Köppen (Ab' Saber, 1986). The monthly average temperature is around 19 to $31^{\circ} \mathrm{C}$, with a drought period that runs from May to October and a rainy period from November to April (Nunes, 2009).

The native species were previously selected based on seed availability and potential for soil cover, whitch were: Bauhinia longipedicellata, Mimosa acutistipula and Solanum crinitum in competition with the exotic grass Urochloa brizantha. Each pot represented an experimental unit, where there a native plant was sown in the center and an exotic plant was sown on the sides. The exotic plant was established at densities ranging from one to five plants per pot, composing a $3 \times 5$ factorial arrangement with four replications, outlined completely at random.

Five-liter pots were used, which were filled with soil substrate composed of an ore sterile cell (3 L), top soil (1 L) and organic compound $(1 \mathrm{~L})$. Chemical fertilization was carried out with $7.5 \mathrm{~g} \mathrm{pot}^{-1}$ of dolomitic limestone for acidity correction, $70 \mathrm{~g} \mathrm{pot}^{-1}$ of NPK in the 4:14:8 formula, $40 \mathrm{~g} \mathrm{pot}^{-1}$ of FTE BR micronutrient and $10 \mathrm{~g} \mathrm{pot}^{-1}$ of natural phosphate. The irrigation of the experiment was performed daily with $5 \mathrm{~mm} \mathrm{pot}^{-1}$ of water blade, $2.5 \mathrm{~mm}$ pot $^{-1}$ in the early morning and $2.5 \mathrm{~mm} \mathrm{pot}^{-1}$ in the late afternoon.

Before sowing, seeds were submitted to a dormancy interruption treatment, according to recommendations for each species available in specific literature: tegument chiseling by immersion in sulfuric acid for 5 minutes for the species Bauhinia longipedicellata and Mimosa acutistipula; immersion in a gibberellin solution for Solanum crinitum seeds, and mechanical scarification for the exotic grass Urochloa brizantha (Souza Filho, Dutra, \& Silva, 1998; Lopes, Barbosa, \& Capucho, 2007; Souza, 2017).

After seed dormancy was broken, sowing was performed according to the specification for treatments with \pm 5 seeds per pit, where the native species' pit was surrounded by a plastic ring in order to divide the native plant from other plants of the top soil seed bank that eventually germinated. 
Ten days after sowing, plants were thinned so that only one plant per pit remained. From the thinning, plants remained in full competition for a period of 40 days (50 days after planting), while at the end of this period, the physiological and morphological evaluation of the native plants was carried out. Using an infrared gas analyzer (model LI-6400XT/LI-COR), the liquid photosynthesis, stomatal conductance and transpiration were measured at constant light levels $\left(1500 \mu \mathrm{mol} \mathrm{m} \mathrm{m}^{-2} \mathrm{~s}^{-1}\right)$ and $\mathrm{CO}_{2}\left(400 \mu \mathrm{mol} \mathrm{m} \mathrm{m}^{-2} \mathrm{~s}^{-1}\right)$. Calculating the ratio between liquid photosynthesis and transpiration, the water use efficiency was obtained.

In the morphological evaluation, the number of tillers and leaves were counted, the height was measured, from the base of the stem to the tip of the newest fully expanded leaf, the leaf area was measured with a leaf area analyzer (model LAI3000/LI-COR) with a precision of $0.1 \mathrm{~cm}^{2}$, and the dry matter of leaves, stem and root of plants were measured. The exotic grass was also evaluated at the end of the competition period in terms of morphology, quantifying the number of tillers, leaf area and dry matter of leaves, stem and root.

In order to analyze the results of the experiment in a multivariate context with a lower dimensionality of variables, the analysis of factors was performed, by maximum likelihood method with varimax rotation (Kaiser, 1958). While selecting the factors, those with eigenvalues greater than or equal to 1.0 were extracted (Hair Jr., Black, Babin, Anderson, \& Tatham, 2009). The original variables were considered highly correlated to the factors when factor loads had values $\geq 0.6$ (Macciotta et al., 2015), from which the practical interpretation of the factors was performed. The adequacy of factor analysis was assessed by applying the Bartlett sphericity test to the 0.05 level of significance.

For factors that could be interpreted, the scores for each individual were calculated using the weighted least squares method (Bartlett, 1937). The calculated scores were submitted to Bartlett's homocedasticity and Shapiro-Wilk normality, both at the 0.05 level of significance, for later analysis of variance and Tukey's test at the 0.05 level for comparison with native species. In order to evaluate the effects of different densities of exotic grass on native plants, a regression analysis was performed. Analyses were performed using the free software $\mathrm{R}$ through the packages 'psych', 'GPArotation' and 'car' (R Core Team, 2017).

\section{Results}

When analyzing the scree-plot graph presented in Figure 1, it is possible to verify that from the fifth factor, the eigenvalues are less than 1.0, so that only the first four factors were selected for the factorial analysis. Under the null hypothesis that the correlation matrix is equal to the identity, the Bartlett sphericity test was significant, that is, the factor analysis is adequate and the accumulated variance explained by the four extracted factors is more than $70 \%$ (Table 1).

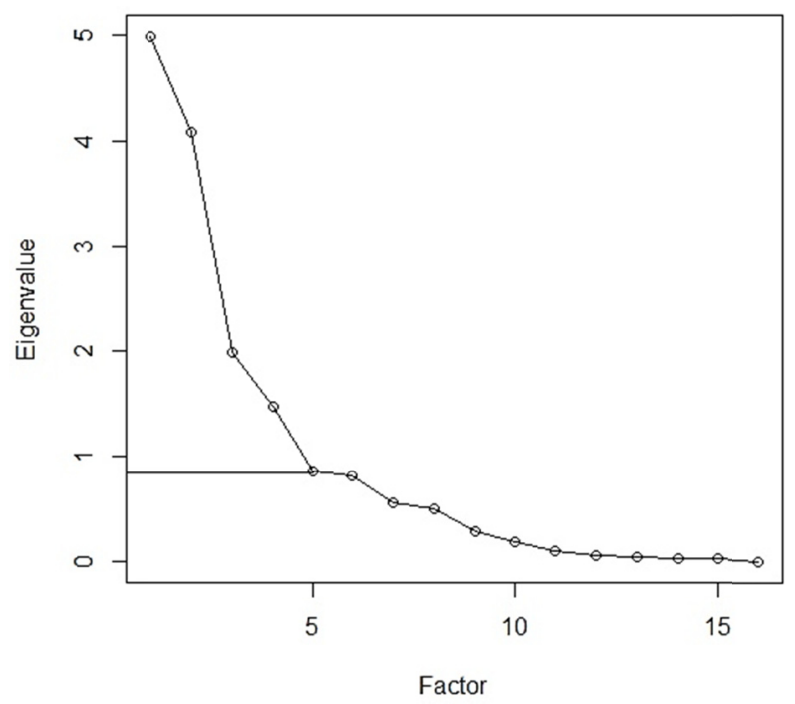

Figure 1. Scree-plot graph 
Table 1. Factorial loads $(\mathrm{r})$, commonalities $\left(\mathrm{h}^{2}\right)$, unicities $(\psi)$, variance $\left(\mathrm{S}^{2}\right)$ explained individually and accumulated by the factors

\begin{tabular}{lllllll}
\hline Variable & Factor 1 & Factor 2 & Factor 3 & Factor 4 & $\mathrm{h}^{2}$ & $\psi$ \\
\hline Leaf dry matter & $---0 .--1$ & & & \\
Stem dry matter & $\mathbf{0 . 9 7}$ & 0.21 & & & 0.98 & 0.02 \\
Root dry matter & $\mathbf{0 . 6 8}$ & & 0.22 & -0.15 & 0.53 & 0.47 \\
Number of tillers & $\mathbf{0 . 6 2}$ & 0.17 & 0.20 & & 0.46 & 0.54 \\
Leaf area & $\mathbf{0 . 6 7}$ & & 0.16 & & 0.48 & 0.52 \\
Height & $\mathbf{0 . 9 5}$ & 0.12 & & & 0.92 & 0.08 \\
Number of leaves & 0.19 & 0.58 & & -0.18 & 0.40 & 0.60 \\
Liquid photosyntesis & $\mathbf{0 . 7 5}$ & -0.15 & 0.11 & -0.11 & 0.61 & 0.39 \\
Transpiration & 0.20 & & $\mathbf{0 . 9 1}$ & 0.34 & 1.00 & 0.01 \\
Water use efficiency & 0.28 & & $\mathbf{0 . 7 9}$ & -0.52 & 0.97 & 0.03 \\
Stomatal conductance & -0.11 & -0.16 & & $\mathbf{0 . 9 5}$ & 0.94 & 0.06 \\
Ex. leaf dry matter* & 0.26 & & $\mathbf{0 . 8 9}$ & -0.27 & 0.93 & 0.07 \\
Ex. stem dry matter & 0.12 & $\mathbf{0 . 9 7}$ & & & 0.97 & 0.03 \\
Ex. root dry matter & 0.14 & 0.25 & & 0.27 & 0.16 & 0.84 \\
Ex. tiller number & & $\mathbf{0 . 8 4}$ & & & 0.72 & 0.28 \\
Ex. leaf area & -0.29 & $\mathbf{0 . 8 5}$ & & & 0.81 & 0.19 \\
$\mathrm{~S}^{2}$ explained (\%) & 0.17 & $\mathbf{0 . 9 5}$ & & & 0.92 & 0.08 \\
$\mathrm{~S}^{2}$ explained accumulated (\%) & 0.26 & 0.24 & 0.15 & 0.09 & & \\
\hline
\end{tabular}

Note. *ex.: morphological parameter of the exotic grass.

When evaluating the communities (Table 1), which quantified the variance of each variable explained by common factors, it was found that at least half of the variance of most of the variables is explained by common factors, with the exception, mainly, of the stem dry matter of the exotic grass variable, since its variance is basically related to specific factors (unicities).

Based on the factorial loads (Table 1), which express the correlation between the original variables and the factors, it was possible to interpret the first three factors, which were called indices. The first factor, called the vegetative growth index (VGI), was highly correlated with the growth variables of native species, except for height; the second factor, called the infestation density index (IDI), corresponded mainly to the growth variables of the exotic grass, except for the stem dry matter; the third factor, defined as physiological quality index (PQI), showed a higher correlation with the physiological variables of native plants, except for water use efficiency.

From the results of the analysis of variance of the indices (Table 2), it was verified that only for the IQF there was a significant difference between native species, whereas, although the Tukey's test did not detect differences between them, Solanum crinitum presented the highest IQF value, whereas the lowest value was associated with Mimosa acutistipula (Table 3).

Table 2. Summary of the analysis of variance of vegetative growth index (VGI), infestation density index (IDI) and physiological quality index (PQI) of the Bauhinia longipedicellata, Mimosa acutistipula and Solanum crinitum in competition with Urochloa brizantha

\begin{tabular}{lllll}
\hline \multirow{2}{*}{ FV } & \multirow{2}{*}{ GL } & \multicolumn{2}{c}{$\mathrm{F}$} \\
\cline { 3 - 5 } & & VGI & IDI & PQI \\
\hline Native species & 2 & $1.21 \mathrm{~ns}$ & $2.73 \mathrm{~ns}$ & $3.40^{*}$ \\
Grass density & 4 & & & \\
Native sp. $\times$ Grass density & 8 & $0.83 \mathrm{~ns}$ & $1.42 \mathrm{~ns}$ & $0.87 \mathrm{~ns}$ \\
Residue & 44 & & & \\
\hline
\end{tabular}


Table 3. Means of vegetative growth index (VGI), infestation density index (IDI) and physiological quality index (PQI) of the three studied native species

\begin{tabular}{llll}
\hline Species & VGI & IDI & PQI \\
\hline Bauhinia longipedicellata & 0.08 & 0.05 & $0.20 \mathrm{a}^{*}$ \\
Mimosa acutistipula & -0.26 & -0.25 & $-0.49 \mathrm{a}$ \\
Solanum crinitum & 0.17 & 0.19 & $0.26 \mathrm{a}$
\end{tabular}

Note. * Means followed by the same letters do not differ according to the Tukey's test at the 0.05 level of significance.

Numerically, the $S$. crinitum species, besides the best PQI, also presented the highest value of VGI, although it was the species that least inhibited the development of Urochloa brizantha, considering the IDI value. The performance of $M$. acutistipula in terms of IDI was the best among the three species, a result that contradicts their VGI and PQI values. However, among the original variables negatively correlated with IDI, the most important is the water use efficiency $(\mathrm{r}=-0.16)$, in which the M. acutistipula species was almost twice as efficient as the others, which partly explains the IDI results.

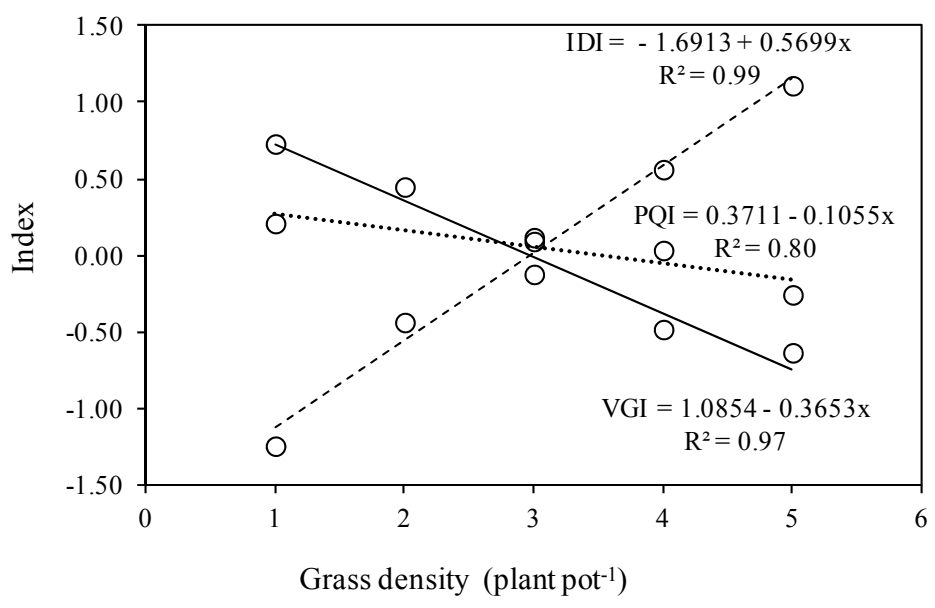

Figure 2. General averages of vegetative growth index (VGI) and physiological quality index (PQI) of the Bauhinia longipedicellata, Mimosa acutistipula and Solanum crinitum and of infestation density index (IDI) of the Urochloa brizantha according to the densities of exotic grasses

When plotting VGI, IDI and PQI data in a single graph (Figure 2), it was found that there is an intersection between the lines at the point where the density of exotic grasses is three plants for a native plant, besides being the point at which the VGI tends to zero, that is, the native plants B. longipedicellata, M. acutistipula and $S$. crinitum have their growth inhibited when in competition with three or more plants of $U$. brizantha. As for the PQI, for each additional $U$. brizantha plant in competition with the native species, there is a reduction of 0.1055 units in the PQI.

\section{Discussion}

The fact that the height variable of the native species present correlation close to considered high with the IDI index that must be related to the competition for light and the consequent tendency to higher plant height growth as an attempt to capture more light (Merotto Jr., Vidal, Fleck, \& Almeida, 2002), i.e., the height of native plants tends to increase in response to increased exotic grass infestation.

Working with three sugarcane cultivars in competition with different densities of $U$. brizantha, Galon et al. (2012) verified on average a $76 \%$ reduction in the yield of cane stems in competition with 4 to $9 \mathrm{U}$. brizantha plants for each planted bud. In the study by Jakelaitis et al. (2006), maize was not affected in terms of productivity in competition conditions with up to eight $U$. brizantha plants, when it was established 14 days after the emergence of the crop. 
As in the species evaluated in the present research, significant reductions in the physiological parameters were also observed for beans (Manabe et al., 2014) and coffee (Matos et al., 2013) in competition with different weed species.

In practice, the recomposition of the native vegetation should be preceded by the desiccation of the exotic grasses with herbicides, a procedure that will facilitate the establishment of native plants. With the advanced growth of native plants, partial shading of the soil will occur, a fact that will limit the development of exotic grasses (Andrade, Valentim, Carneiro, \& Vaz, 2004; Martuscello, Jank, Gomtijo Neto, Laura, \& Cunha, 2009).

Although not significant, the superior performance of the S. crinitum species in relation to the others suggests the existence of more efficient adaptive mechanisms. As described by Dias-Filho (1997), the S. crinitum species has the ability to adjust its morphology and physiology in order to maintain satisfactory growth even under conditions of low photosensitivity in response to low light availability. According to the author, the species tends to direct more carbon to the components of the plant shoot, reducing the development of roots.

\section{Conclusions}

The analysis of factors was adequate, reducing data volume to four factors, three of which could be interpreted and defined as vegetative growth index, infestation density index and physiological quality index. Among the studies native species from the National Forest of Cajarás, Solanum crinitum was slightly superior to the others in terms of vegetative growth index and of physiological quality index. Generally speaking, native species maintain their vegetative growth in competitive condition with up to two Urochloa brizantha plants; above that, the vegetative growth index tends to zero, while the infestation density index becomes positive.

\section{Acknowledgements}

VALE S.A. for financial assistance.

\section{References}

Aarssen, L. W. (1983). Ecological Combining ability and competitive combining ability in plants: Toward a general evolutionary theory of coexistence in systems of competition. The American Naturalist, 122(6), 707-731. https://doi.org/10.1086/284167

Ab'Saber, A. N. (1986). Geomorphology of the region. In J. M. G. Almeida Jr. (Org.), Carajás: Political challenge, ecology and development (pp. 88-124). São Paulo: Brasiliense.

Andrade, C. M. S., Valentim, J. F., Carneiro, J. C., \& Vaz, F. A. (2004). Growth of tropical forage grasses and legumes under shade. Pesquisa Agropecuária Brasileira, 39(3), 263-270. https://doi.org/10.1590/S0100204X2004000300009

Bartlett, M. S. (1837). Properties of sufficiency and statistical tests. Proceedings of the Royal Society of London A, 160, 268-282. https://doi.org/10.1098/rspa.1937.0109

Bianchi, M. A., Fleck, N. G., \& Lamego, F. P. (2006). Proportion among soybean and competitor plants and the relations of mutual interference. Ciência Rural, 36(5), 1380-1387. https://doi.org/10.1590/S0103-84782 006000500006

Carvalho, F. P., Santos, J. B., Cury, J. P., Valadão Silva, D., Braga, R. R., \& Byrro, E. C. M. (2011). Alocation of dry matter in maize cultivars in competition with weed. Planta Daninha, 29(2), 373-382. https://doi.org/ 10.1590/S0100-83582011000200015

Cavalcanti Filho, L. F. M., Santos, M. V. F., Ferreira, M. A., Lira, M. A., Modesto, E. C., Dubeux Jr., J. C. B., ... Silva, M. J. (2008). Characterization of brachiaria decumbens pastures in the Coastal Region of Pernambuco. Archivos de Zootecnia, 57(220), 391-402.

Costa, G. G. O., Souza, R. C., \& Gouvea, V. H. C. (2007). An inferential procedure for factor analysis using bootstrap and jackknife techniques: construction of confidence intervals and tests of hypotheses. Revista Universidade Rural Série Ciências Exatas e da Terra, 26(1-2), 33-44.

Dias-Filho, M. B. (1997). Physiological response of Solanum crinitum Lam. Pesquisa Agropecuária Brasileira, 32(8), 789-796.

Galon, L., Tironi, S. P., Silva, A. F., Beutler, A. N., Rocha, P. R. R., Ferreira, E. A., \& Silva, A. A. (2012). Macronutrients availability in sugarcane varieties grown under increasing densities of Brachiaria brizantha. Ciência Rural, 42(8), 1372-1379. https://doi.org/10.1590/S0103-84782012000800007 
Goldberg, D. E., \& Landa, K. (1991). Competitive effect and response: Hierarchies and correlated traits in the early stages of competition. Journal of Ecology, 79(4), 1013-1030. https://doi.org/10.2307/2261095

Golder Associates. (2008). Consolidated report of the flora from AID/ADA of the Ferro Carajás S11D Project. Belo Horizonte, Brazil.

Hair Jr., J. F., Black, W. C., Babin, B. J., Anderson, R. E., \& Tatham, R. L. (2009). Multivariate data Analysis (7th ed.). Upper Saddle River: Prentice Hall.

Holanda, F. S. R., Rocha, I. P., \& Oliveira, V. S. (2008). Riverbank stabilization with soil bioengineering techniques at the Lower São Francisco River. Revista Brasileira de Engenharia Agrícola e Ambiental, 12(6), 570-575. https://doi.org/10.1590/S1415-43662008000600002

IBGE. (2012). Manual técnico da vegetação brasileira (2nd ed.). Rio de Janeiro: IBGE.

Jakelaitis, A., Silva, A. F., Pereira, J. L., Silva, A. A., Ferreira, L. R., \& Vivian, R. (2006). Effects of density and emergence period of Brachiaria brizantha in competition with maize plant. Acta Scientiarum Agronomy, 28(3), 373-378.

Kaiser, H. F. (1958). The varimax criterion for analytic rotation in factor analysis. Psychometrika, 23, $187-200$. https://doi.org/10.1007/BF02289233

Kuva, M. A., Gravena, R., Pitelli, R. A., Christoffoleti, P. J., \& Alves, P. L. C. A. (2001). Interference periods of weeds in the sugarcane crop. III-Brachiaria decumbens and Panicum maximum. Planta Daninha, 19(3), 323-330. https://doi.org/10.1590/S0100-83582001000300003

Kuva, M. A., Pitelli, R. A., Christoffoleti, P. J., \& Alves, P. L. C. A. (2000). Interference periods of weeds in the sugarcane culture. I-Purple nutsedge. Planta Daninha, 18(2), 241-251. https://doi.org/10.1590/S0100-83582 000000200006

Levine, J., \& D'antonio, C. M. (1999). Elton revisited: A review of the evidence linking diversity and invasibility. Oikos, 87, 1-12. https://doi.org/10.2307/3546992

Lopes, J. C., Barbosa, L. G., \& Capucho, M. T. (2007). Germination of seeds of Bauhinia spp. Floresta, 37(2), 265-274. https://doi.org/10.5380/rf.v37i2.8658

Macciotta, N. P., Dimauro, C., Null, D. J., Gaspa, G., Cellesi, M., \& Cole, J. B. (2015). Dissection of genomic correlation matrices of US Holsteins using multivariate factor analysis. Journal of Animal Breeding and Genetics, 132, 9-20. https://doi.org/10.1111/jbg.12113

Manabe, P. M. S., Matos, C. C., Ferreira, E. A., Silva, A. A., Sediyama, T., Manabe, A., ... Galon, L. (2014). Physiological characteristics of beans in competition with weed. Bioscience Journal, 30(6), 1721-1728.

Martuscello, J. A., Jank, L., Gontijo Neto, M. M., Laura, V. A., \& Cunha, D. N. F. V. (2009). Genus Brachiaria grass yields under different shade levels. Revista Brasileira de Zootecnia, 38(7), 1183-1190. https://doi.org/ 10.1590/S1516-35982009000700004

Matos, C. C., Fialho, C. M. T., Ferreira, E. A., Silva, D. V., Silva, A. A., Santos, J. B., ... Galon, L. (2013). Physiological characteristics of coffee plants in competition with weeds. Bioscience Journal, 29(5), 1111-1119.

Merotto Jr., A., Vidal, R. A., Fleck, N. G., \& Almeida, M. L. (2002). Weed interference in the initial development of soybean and rice plants through light quality. Planta Daninha, 20(1), 9-16.

Nunes, J. A. (2009). Floristics, structure and soil-vegetation relationships in a phyto-physiognomic gradient over 'canga', in the southern range, Carajás National Forest-Pará (Master's thesis, Federal University of Viçosa, Viçosa, Brazil).

Pereira, D., Santos, D., \& Carvalho, M. (1993). Geography: space science (4nd ed.). São Paulo: Atual.

Pitelli, R. A. (1985). Interference of weeds in agricultural crops. Informe Agropecuário, 11(129), 16-27.

R Core Team. (2017). R: A language and environment for statistical computing. R Foundation for Statistical Computing, Vienna.

Rigoli, R. P., Agostinetto, D., Schaedler, C. E., Dal Magro, T., \& Tironi, S. (2008). Relative competitive ability of wheat (Triticum aestivum) intercropped with Italian ryegrass (Lolium multiflorum) or wild radish (Raphanus raphanistrum). Planta Daninha, 26(1), 93-100. https://doi.org/10.1590/S0100-83582008000 100010 
Souza Filho, A. P. S., Dutra, S., \& Silva, M. A. M. M. (1998). Dormancy overcoming methods of weed seeds from Amazonian cultivated pasture. Planta Daninha, 16(1), 3-11. https://doi.org/10.1590/S0100-8358199 8000100001

Souza, R. R. (2017). Development, anatomy and nutrition of Mimosa acutistipula var. ferrea, Solanum crinitum and Zea mays under iron doses (Master's thesis, Federal University of Lavras, Lavras, Brazil).

\section{Copyrights}

Copyright for this article is retained by the author(s), with first publication rights granted to the journal.

This is an open-access article distributed under the terms and conditions of the Creative Commons Attribution license (http://creativecommons.org/licenses/by/4.0/). 